\title{
Physiological analysis and heat-resistant protein (LEA) activity in squash hybrid seeds during development ${ }^{1}$
}

\author{
Patricia Pereira da Silva², Antônio Carlos Souza Albuquerque Barros ${ }^{3}$, \\ Edila Vilela de Resende Von Pinho ${ }^{4}$, Warley Marcos Nascimento ${ }^{5 *}$
}

\begin{abstract}
This study has aimed to evaluate the best time to harvest squash seeds and verify the effect of fruit storage on protein activity and in the physiological quality of 'Jabras' squash hybrid seeds. The fruits were harvested at 15, 30, 45, 60 and 75 days after anthesis (DAA). In every period, thirty fruits were harvested and fifteen had their fruit extracted immediately after harvesting, and the other fifteen fruits were stored for twenty days in plastic boxes under shade conditions, and only after this period the seeds were extracted. Seed quality was evaluated for the following parameters: moisture content, germination, first count, germination rate, seedling emergence, emergence rate, seed mass and seedling dry matter. Also, the electrophoretic profile analysis of heat-resistant proteins (Late Embryogenesis Abundant - LEA) was performed. Seed physiological maturity occurred in fruits harvested at 60 days after anthesis and stored for 20 days. During this period, seeds reached the maximum dry matter, maximum germination and vigor, and a high concentration of LEA proteins.
\end{abstract}

Index terms: Cucurbita maxima, Cucurbita moschata, seed quality.

\section{Análise fisiológica e atividade de proteínas resistentes ao calor (LEA) em sementes híbridas de abóbora durante o desenvolvimento}

\begin{abstract}
RESUMO - O objetivo nesse trabalho foi avaliar a melhor época para a realização da colheita e verificar o efeito do armazenamento dos frutos na atividade de proteínas e na qualidade fisiológica de sementes do híbrido de abóbora 'Jabras'. Os frutos foram colhidos aos 15, 30, 45, 60 e 75 dias após a antese (DAA). Em cada época, foram colhidos trinta frutos, sendo que quinze frutos tiveram suas sementes extraídas imediatamente após a colheita e os outros quinze frutos foram armazenados por vinte dias em caixas plásticas em condições de galpão, e somente após este período, tiveram suas sementes extraídas. Avaliou-se a qualidade das sementes por meio do grau de umidade, germinação, primeira contagem, índice de velocidade de geminação, emergência, índice de velocidade de emergência, massa de 1000 sementes e massa seca de plântulas, além da análise do perfil eletroforético de proteínas resistentes ao calor (Late Embryogenesis Abundant - LEA). A maturidade fisiológica das sementes ocorreu em sementes oriundas de frutos colhidos aos 60 dias após a antese e armazenados por 20 dias. Nesse período, as sementes encontravam-se com o máximo de matéria seca, máxima germinação e vigor e alta concentração de proteínas LEA.
\end{abstract}

Termos para indexação: Cucurbita maxima, Cucurbita moschata, qualidade das sementes.

\section{Introduction}

Embrapa Hortaliças [Embrapa Vegetables (Brazilian Corporation for Agricultural Research (EMBRAPA Empresa Brasileira de Pesquisa Agropecuária), a state-owned research corporation affiliated with the Brazilian Ministry of Agriculture, Livestock and Food Supply)] released in 1992 a squash interspecific F1 hybrid ('Jabras') with national

${ }^{1}$ Submitted on 5/28/2015. Accepted for publication on 9/9/2015. ${ }^{2}$ Universidade Federal de Pelotas, 70351970 - Pelotas, RS, Brasil. ${ }^{3}$ Universidade Federal de Pelotas, Caixa Postal 354, 96010-900 - Pelotas, RS, Brasil. technology, with the aim of providing to the market a similar product to the imported hybrid. It is a hybrid resulting from crossing between Cucurbita maxima Duch (female parent) and Cucurbita moschata Duch (male parent), with characteristics such as higher precocity and more uniform fruits when compared to open pollination regional cultivars (Nascimento et al., 2011).

A major factor in this hybrid seed production process is to

${ }^{4}$ Departamento de Agricultura, UFLA, Caixa Postal 3037, 37200-000 Lavras, MG, Brasil.

${ }^{5}$ Embrapa Hortaliças, Caixa Postal 218, 70359-970 - Brasília, DF, Brasil.

*Corresponding author <warley.nascimento@embrapa.br> 
determine the period of seed physiological maturity to avoid incorrect harvest that could impair their quality, since there is not always the need for full fruit maturity in the field. After harvesting the fruits and subsequent storage period, the unripe seeds (or not fully ripe) can complete their development within the fruit, reaching maximum rates of germination and vigor.

In the early stages of development, the seeds are not able to tolerate desiccation. Tolerance acquisition is related to two protecting mechanisms which may be installed before or during the seed dehydration stage: the soluble sugars synthesis and the LEA (Late Embryogenesis Abundant) protein synthesis (Hoekstra et al., 2001). The LEA proteins are hydrophilic, stable, do not denature at high temperatures, are synthesized in seeds during development, when the abscisic acid (ABA) content is still high, and during the rapid dehydration stage, which occurs late in maturation process (Han et al.,1997). During seed maturity, the acquisition of desiccation tolerance may coincide with physiological maturity. The ability to germinate after the harvesting precedes the ability development to germinate after harvest and rapid artificial drying. Some studies report that the LEA proteins may also be accumulated in response to water stress, low temperature or salinity (Hong-Bo et al., 2005).

Physiological seed maturity is closely related to the ideal time to harvest, promoting the preservation of its physiological quality after harvesting. Thus, obtaining seeds with high physiological quality depends on the precise identification of the ideal time of harvesting, which often corresponds to the time when physiological maturity is reached, also coinciding with the moment of maximum dry matter accumulation, high vigor and high germination potential (Carvalho and Nakagawa, 2000).

Identifying the physiological maturity point to determine the correct time for fruit harvesting and extracting the seeds is of utmost importance in establishing efficient systems for commercial production. The unnecessary stay of fruits in field conditions, for example, results in progressive seed deterioration influenced by environmental conditions. In the maturity of fleshy fruit seeds, including cucurbitaceae, an outstanding feature is the continuation of the seed maturation even after the fruit harvesting (Vidigal et al., 2006). Unripe seeds from fleshy unripe fruits may have physiological quality comparable to ripe fruit seeds, provided that they are properly stored (Carvalho and Nakagawa, 2000). The possibility of holding early fruits, with subsequent storage, may be an interesting alternative for the grower of cucurbitaceae seeds (Barbedo et al., 1994). This issue has been extensively studied in seeds from fleshy fruits, as is the case of squash (Araújo et al., 1982), watermelon (Alvarenga et al., 1984) and cucumber (Barbedo et al., 1999), among others. In the specific case of hybrid squash, there are reports indicating that fruit storage is essential to ensure the seed physiological quality (Costa et al., 2006).

Thus, the aim of this study was to evaluate the best time for harvest and check the fruit storage effect on physiological quality of 'Jabras' squash hybrid seeds by means of physiological studies and heat-resistant proteins (LEA) activity during seed development and maturation.

\section{Material and Methods}

Hybrid squash seeds derived from cross between Cucurbita maxima (female parent) and Cucurbita moschata (male strain) were produced in greenhouse in an experimental field at Embrapa Hortaliças, in Brasília, DF, from May to October 2012 period. Manual pollination was used, held in the early hours of the day, followed by labeling of pollinated flowers, with an average ratio of one male flower to three female flowers.

Fruit were harvested at 15, 30, 45, 60 and 75 days after anthesis (DAA). In every period, thirty fruits were harvested, with fifteen fruits being stored for twenty days in plastic boxes of a shaded and airy conditions. The remaining fruit had their seeds extracted immediately after harvesting, using hydrated lime for mucilage removal. Then the seeds were washed in tap water and dried at room temperature for 24 hours. In the next step, seeds were transferred to a chamber with ventilation and temperature of $32{ }^{\circ} \mathrm{C}$ for 48 hours. The dried seeds were then blowed in a pneumatic machine. The same procedure was performed with the seeds from the stored fruits. Seeds were subjected to the following analyses:

Determination of moisture content: the oven method at $105^{\circ} \mathrm{C}$ for 24 hours was used, according to the Regras para Análise de Sementes (RAS; Rules for Seed Testing) (Brasil, 2009). About $2 \mathrm{~g}$ of seeds were used in each container, with two replicates for each treatment.

Germination: four replications of 50 seeds of each treatment were placed on a germitest-type paper roll moistened with distilled water at a ratio of 2.0 times the dry paper mass and incubated in a germination chamber with alternating temperatures of $20{ }^{\circ} \mathrm{C}(16 \mathrm{~h}$, dark $)$ and $30{ }^{\circ} \mathrm{C}(8 \mathrm{~h}$, light $)$. A count at eight days after the test establishment was carried out and evaluations were done according to criteria established by the Regras para Análise de Sementes (RAS; Rules for Seed Testing) (Brasil, 2009).

First count: it was held together with the germination test, counting the number of normal seedlings present on the fourth day after beginning the test. The results were expressed as percentages (Brasil, 2009).

Germination rate index: obtained by means of daily 
counts of germinated seeds until the eighth day after sowing and calculated by the formula proposed by Labouriau, (1983), with the results being expressed in days.

Seedling emergence in a greenhouse: four replicates of 100 seeds of each treatment were used, which were sown in polystyrene multicellular trays expanded with 200 cells containing a commercial substrate. Irrigation was performed daily. The evaluation was performed 15 days after sowing and the results were expressed as a percentage.

Emergence rate index: obtained by daily counts of germinated seeds until the emergence stabilization, i.e., 15 days after sowing and calculated according to the germination rate described above.

Seed mass: eight subsamples of 100 dry seeds from each treatment were weighed and the average of the results was expressed in grams (g) (Brasil, 2009).

Seedling dry matter: held on 50 seedlings (shoot) obtained at 20 days after emergence, in the previously mentioned test. The samples were placed in brown paper envelopes which were weighed, identified and oven dried $\left(65^{\circ} \mathrm{C}\right)$ for a period of 48 hours. After this period, seedlings were kept in a desiccator for 15 minutes, determining the dry matter on a precision balance in mg.seedling ${ }^{-1}$.

Heat-resistant proteins analysis - LEA (Late Embryogenesis Abundant): performed at Laboratório Central de Sementes (Central Laboratory of Seeds), Lavras Federal University, from February to May 2013. 100 mg of embryonic axes were macerated in crucibles in the presence of liquid nitrogen and then, extraction buffer was added at a ratio of 10 parts of buffer to 1 part of the sample. The samples were centrifuged at $14,000 \mathrm{rpm}$ for 30 minutes at $4{ }^{\circ} \mathrm{C}$. The supernatant was removed and incubated in a water bath at $85^{\circ} \mathrm{C}$ for 15 minutes. Then, centrifugation was repeated as mentioned above. Subsequently, $70 \mu \mathrm{L}$ of the extract were collected, put into microtubes and $40 \mu \mathrm{L}$ of sample buffer were added (Tris $\mathrm{HCl} 50 \mathrm{mM} \mathrm{pH} \mathrm{7.5).} \mathrm{Subsequently,} \mathrm{a} \mathrm{hole}$ was made in the lid of each microtube and they were placed in their own support, which was placed in boiling water for 5 minutes. At the end of this period, electrophoretic run described by Alfenas (2006) was carried out. The gels staining was performed with the use of $0.05 \%$ Coomassie Blue solution for 12 hours, and discoloration, until visualization of the bands, with $10 \%$ acetic acid solution.

The tests were carried out in a completely randomized design with four replications in a $5 \times 2$ (five harvest seasons and two fruits storage periods) factorial arrangement. Data were subjected to analysis of variance, and the means comparison was done by Tukey's test $(\mathrm{p} \leq 0.05)$. After analysis of variance, regression analysis was performed by the PROC
REG procedure of the computer software SAS (SAS 9.1.3, 2000-2004). Analysis interpretation of the LEA proteins was based on visual analysis of gel electrophoresis, taking into account the presence/absence and the intensity of each of the electrophoretic bands.

\section{Results and Discussion}

The seed moisture content decreased continuously as the fruit age increased. For non-stored fruits, moisture content was $84 \%$ in seeds extracted from fruits at 15 DAA, and $45 \%$ in those extracted from fruits at 75 DAA. As for the fruits stored for 20 days, the moisture content was $76 \%$ in seeds extracted from fruits at 15 DAA, and $40 \%$ in those extracted from fruits at 75 DAA (Figure 1). This moisture is considered high and there is the need for quick drying to prevent possible fermentation and formation of products which result in immediate damage to the seed quality (Marcos-Filho, 2005). After drying, seeds presented moisture between $6 \%$ and $9 \%$. It is recommended moisture for squash seed storage in waterproof packaging is $6 \%$ (Nascimento et al., 2008).

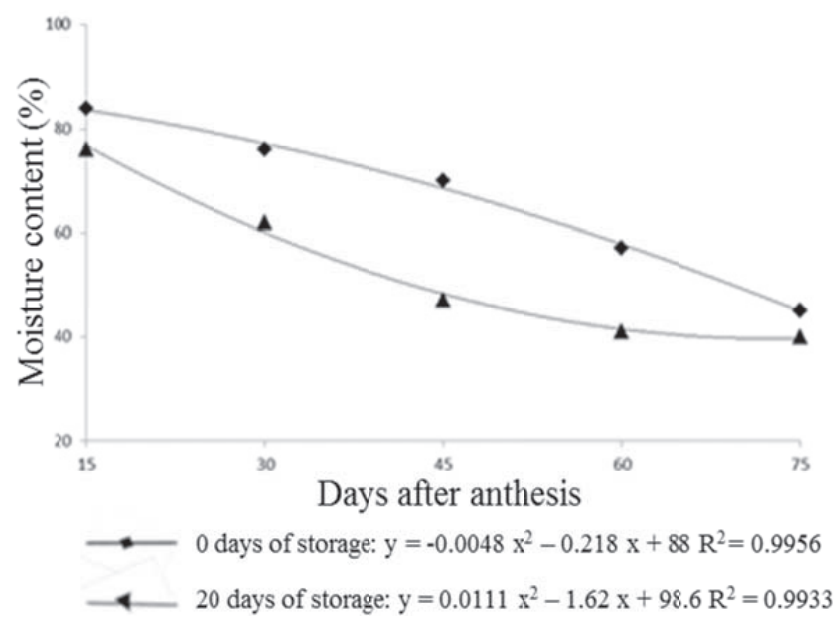

Figure 1. Moisture content of squash hybrid seeds before drying from fruits harvested at 15, 30, 45, 60 and 75 days after anthesis (DAA) and stored for 0 and 20 days.

Similar results were observed by other authors in fleshy fruits, such as by Alvarenga et al. (1984), with Italian squash, whose seed moisture content decreased from $89 \%$ to $42 \%$ throughout the harvesting period. As in pepper seeds, Vidigal et al. (2008) have found that seed moisture content ranges from $96 \%$ at $20 \mathrm{DAA}$ to $46 \%$ at $70 \mathrm{DAA}$, at which time the seed has reached physiological maturity. In fleshy fruit species, osmotic equilibrium occurs between rich solute pericarp and seeds, resulting in stabilization of their moisture content at 
the end of maturation. Although it is used in determining physiological maturity, moisture content from fleshy fruits is not a suitable indicator because it is affected by environmental and genetic influences (Welbaum and Bradford, 1988).

The high initial moisture content found in the seeds of the first harvesting and its subsequent decrease are related to the importance of water in the seeds during and maturation filling and maturation processes. For the photosynthates products in the leaves to be deposited on the seed formation as a construction material and subsequently reserve, it is necessary that this moisture remain high, which occurs until the maximum accumulation of dry matter, when rapid dehydration begins (Carvalho and Nakagawa, 2000).

Significant differences were also found among harvesting periods regarding seed germination in fruits stored for 20 days. Seed germination increased, and relative stability was observed between 60 and 75 DAA, this period being considered as a possible indication of seed physiological maturation, which have attained maximum germination (97\%) at 75 DAA (Figure 2). At this point, seeds produced were able to meet the commercial standards for squash seeds (germination $=80 \%$ ), established by Ministry Administrative Regulation no. 457, of 12/18/1986 (Brasil, 1986). It was also found that the seeds from fruits stored for 20 days numerically showed higher germination compared with those seeds extracted immediately after fruit harvesting (Figure 2). Importantly, fruit storage for 20 days contributed to seed quality improvement, as may be observed in fruits harvested at 75 DAA, being $84 \%$ for non-stored and $97 \%$ for those stored. Similar results were obtained by Vidigal et al. (2009b) in pepper seeds, where higher physiological quality was observed in seeds from fruits harvested at $75 \mathrm{DAA}$ and stored for seven days.

Generally, the harvesting period depends on the seed physiological maturity, which, in most cases, coincides with the maximum accumulation of dry matter, and when the seeds reach this stage, usually their potential for germination and vigor increases (Duarte and Carneiro, 2009). The seed vigor modifications occur in parallel with the transfer progress of plant dry matter for the seeds, i.e., the proportion of vigorous seeds increases during maturation, reaching a maximum at a time that is very close to or coincident with the maximum accumulation of reserves (Marcos-Filho, 2005).

Seed vigor, determined by the first count and germination rate index tests, increased with age and fruit storage (Figure 3). In these two tests, increase in the old vigor obtained from fruits harvested at 60 DAA and stored for 20 days was observed. Similar results were observed by Barbedo et al. (1997) in cucumber seeds. In Italian squash seeds, storing for nine days fruits harvested at 55, 65 and 75 DAA was also beneficial to the vigor, measured by the germination first count (Alvarenga et al., 1984).

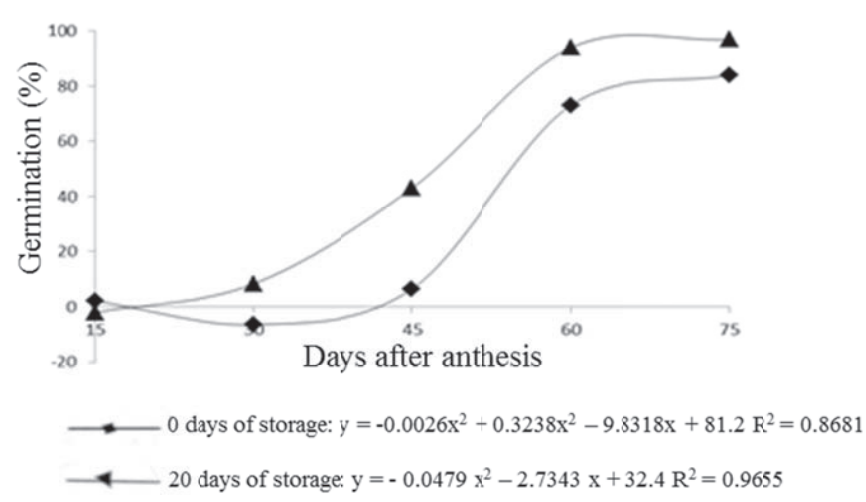

Figure 2. Germination of squash hybrid seeds from fruits harvested at 15, 30, 45, 60 and 75 days after anthesis (DAA) and stored for 0 and 20 days.
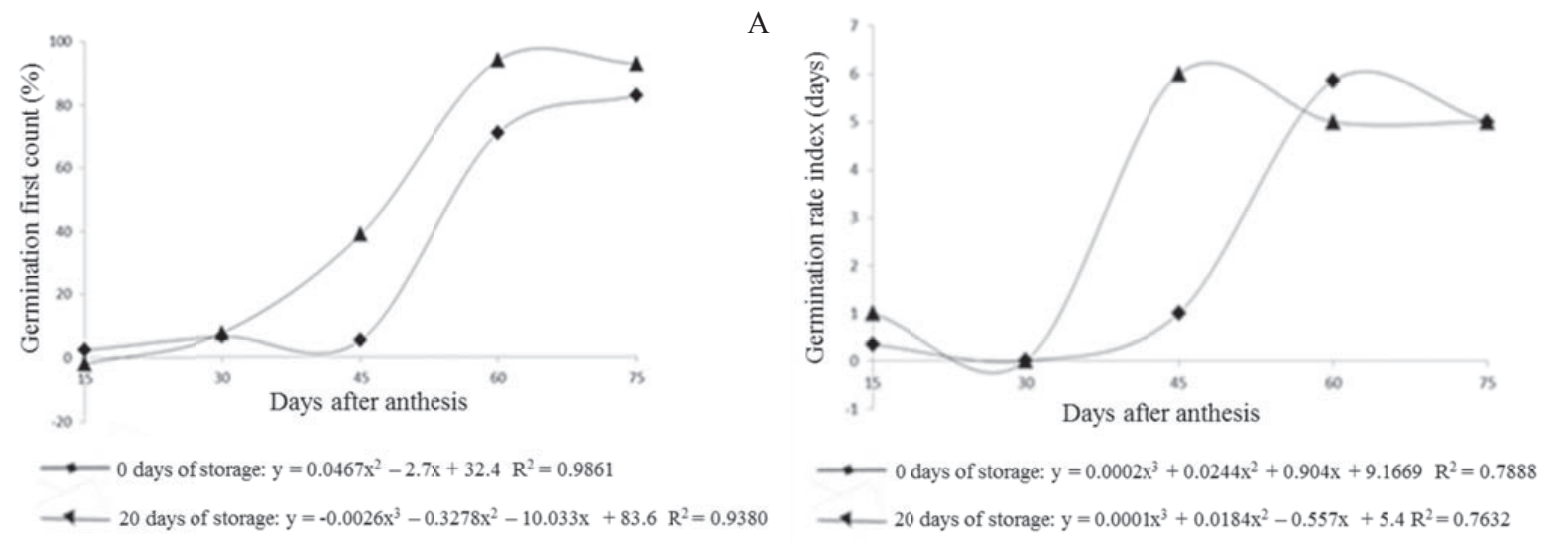

Figure 3. Germination first count (A) and germination rate index (B) of squash hybrid seeds from fruits harvested at 15, 30, 45, 60 and 75 days after anthesis (DAA) and stored for 0 and 20 days. 
Seedling emergence in greenhouse and emergence rate index increments were also observed with advancing age and fruit storage (Figure 4). Seedling emergence was $94 \%$ in seeds from fruits harvested at 45 DAA and stored for 20 days and $97 \%$ in seeds from fruits harvested at $60 \mathrm{DAA}$ and stored for 20 days. Higher emergence rate was obtained in seeds from fruits harvested at 45 days and stored for 20 days (Figure 4).

In the Figure 5 are the results for the seed mass (M1000), which were maximum for those from fruits harvested at 75 DAA and stored for 20 days, averaging $21.53 \mathrm{~g}$. It was observed that the seeds from stored fruits showed higher mass compared to seeds from non-stored fruits throughout the harvesting period. Seed mass is one factor that may influence germination and seedling vigor. Higher weight (or size) seeds usually have well-formed embryos and larger amounts of reserves, being potentially the most vigorous and having higher potential for survival (Carvalho and Nakagawa, 2000). For seedling shoots, growth was observed according to fruit age, and seeds from fruits harvested between 60 and 75 DAA, stored or not, showed similar results (Figure 6).
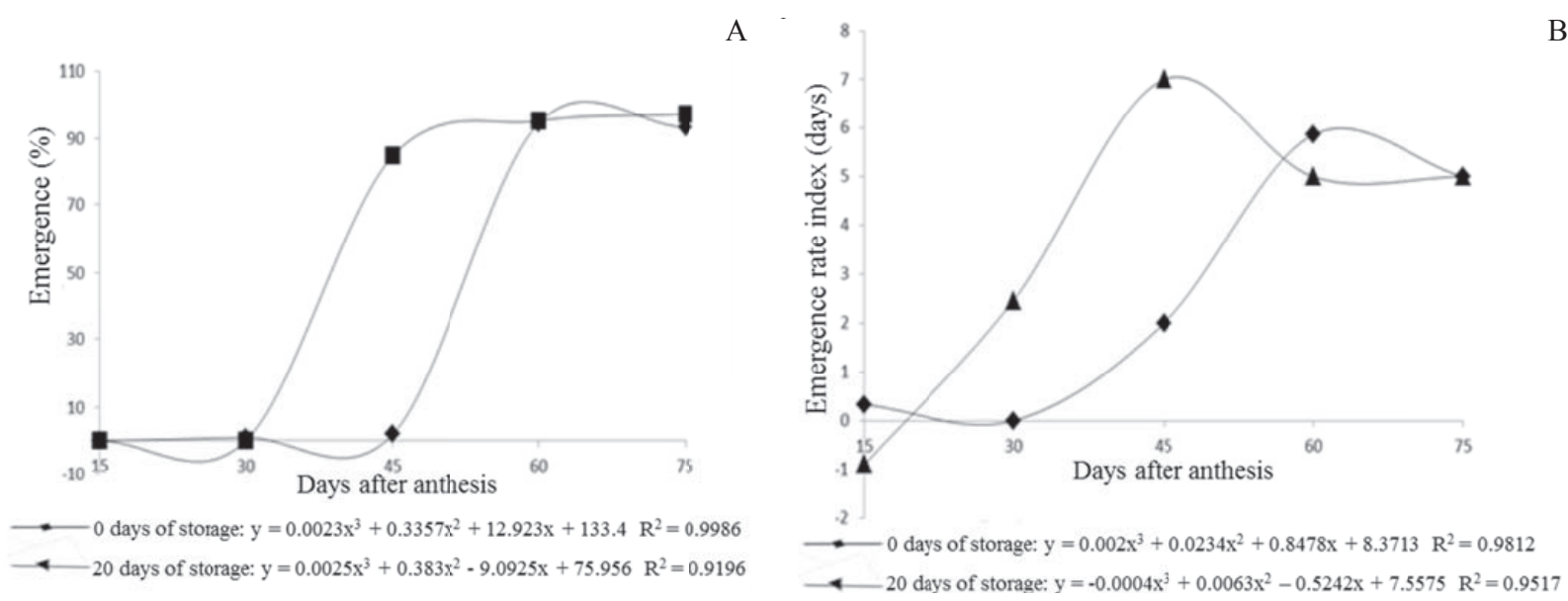

B

Figure 4. Seedling emergence (A) and seedling emergence rate in a greenhouse (B) of squash hybrid seeds from fruits harvested at $15,30,45,60$ and 75 days after anthesis (DAA) and stored for 0 and 20 days.

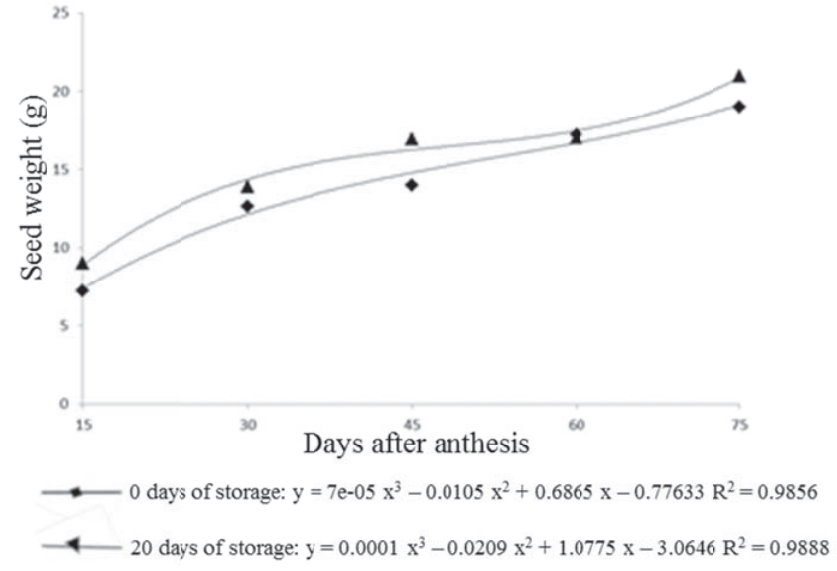

Figure 5. Squash hybrid seed mass from fruits harvested at 15, $30,45,60$ and 75 days after anthesis (DAA) and stored for 0 and 20 days.

Seeds from fruits from the 60 DAA are well formed and with high physiological quality, as seen in the results of germination, vigor and seed mass (Figures 2, 3 and 5).

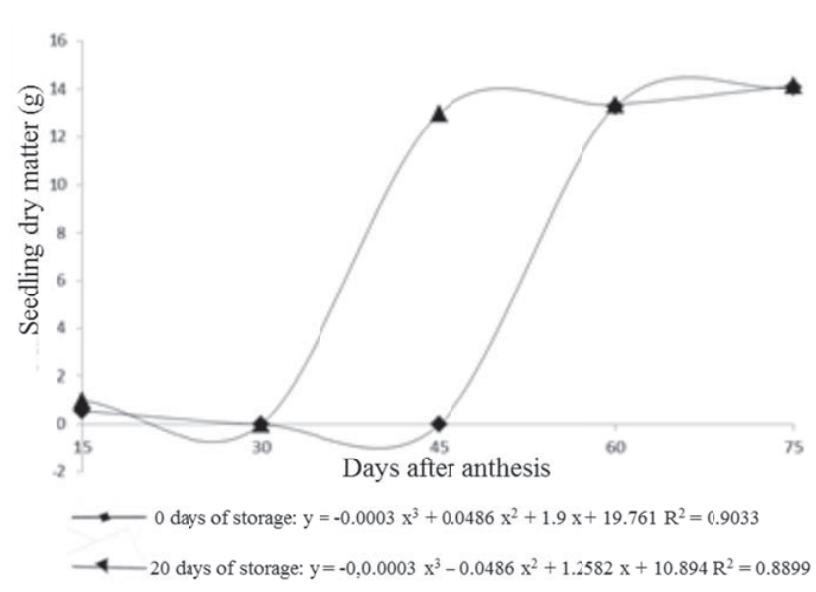

Figure 6. Squash hybrid seedling dry matter from fruits harvested at 15,30, 45, 60 and 75 days after anthesis (DAA) and stored for 0 and 20 days.

Seedlings from high physiological potential seeds have higher efficiency in the production of dry biomass, and reduced differences in plant development (Mondo et al., 2012). These 
results corroborate those found in this study.

The electrophoretic profile of "Late Embryogenesis Abundant" (LEA) proteins demonstrates the absence of bands in the early stages of seed maturation, i.e., until the 30 DAA without fruit storage (Figure 7). Protein expression was initiated in the seeds from fruits harvested at 30 DAA and stored for 20 days; its higher thickness being visible when the maturation stages became more advanced, showing higher activity from 60 DAA, with 20 days of fruit storage. This indicates that from this time seeds probably acquire tolerance to drying, a characteristic that is associated with the time when physiological maturity is reached, which generally coincides with the seeds highest quality (Bewley and Black, 1994). The LEA proteins low activity during the early stages of seed maturation show that, probably, during this phase the seeds were unripe and thus still showed no efficiency in their free radical removal mechanism, promoting their low physiological quality. This result coincides with those obtained in the germination and first count tests (Figures 5 and 6) when it was possible to observe better seed physiological quality with the advance of the maturation process. Similar results were observed in cucumber by Nakada et al. (2011), who found a higher expression of LEA proteins in seeds that had higher physiological maturity. The band electrophoretic pattern analysis of these proteins may facilitate the timely detection of physiological maturation. In another study, the absence of LEA proteins in the early stages of maize seed development was also observed (Faria et al., 2004). During the seed drying process, changes may occur in the relative composition of membrane phospholipids (Dussert et al., 2006), heat-resistant protein synthesis, and the seeds ability to prevent, tolerate or repair damage caused by free radicals. In this process, heat-resistant proteins such as LEA proteins have an important role in preventing the damage caused by drying (Vidigal et al., 2009a), accumulating in response to the abscisic acid (ABA) in the late stages of seed maturation. Thus, seed development process determines the most appropriate procedures for obtaining high quality seeds. It is undeniable that the seed maximum physiological potential is achieved almost simultaneously to maturation (Carvalho and Nakagawa, 2000).

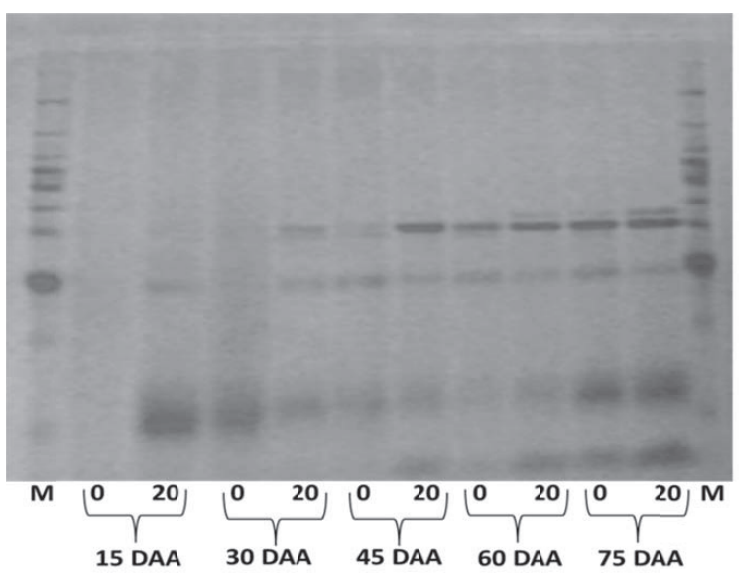

Figure 7. LEA proteins electrophoresis profile in squash hybrid seeds obtained from fruits harvested at 15 , 30, 45, 60 and 75 DAA and stored for 0 and 20 days.

\section{Conclusions}

Physiological maturity of 'Jabras' squash seeds began after 60 DAA, and the seeds from fruits stored for 20 days showed higher physiological quality than those from nonstored fruit.

\section{References}

ALFENAS, A.C. Eletroforese e marcadores bioquímicos em plantas e microrganismos. Viçosa: UFV, 2006. 627p.

ALVARENGA, E.M.; SILVA, R.F.; ARAÚJO, E.F.; CARDOSO, A.A Influência da idade e armazenamento pós-colheita dos frutos na qualidade de sementes de melancia. Horticultura Brasileira, v.2, n.2, p.5-8. 1984. http:// www.scielo.br/scielo.php?script $=$ sci_nlinks\&ref $=000092 \&$ pid $=$ S0101$3122200600010001800001 \& \operatorname{lng}=\mathrm{em}$

ARAÚJO, E.F.; MANTOVANI, E.C.; SILVA, R.F Influência da idade e armazenamento dos frutos na qualidade de sementes de abóbora. Revista Brasileira de Sementes, v.4, n.1, p.77-87, 1982. http://www. scielo.br/scielo.php? script $=$ sci_nlinks\&ref $=000094 \&$ pid $=$ S 0101 3122200600010001800003\&lng=en

BARBEDO, C.J.; BARBEDO, A.S.C.; NAKAGAWA, J.; SATO, O. Efeito da idade e do repouso pós-colheita de frutos de pepino na semente armazenada. Pesquisa Agropecuária Brasileira, v.35, p.839-847, 1999. http://dx.doi. org/10.1590/S0100-204X1999000500015

BARBEDO, C.J.; NAKAGAWA, J.; BARBEDO, A.S.C.; ZANIN A.C.W. Influência da idade e do período de repouso pós-colheita de frutos de pepino cv. Rubi na qualidade fisiológica de sementes. Horticultura Brasileira, v.12, p.14-18, 1994. http://www.scielo.br/scielo.php?script=sci nlinks\&ref=000066\&pid=S0100-204X199900050001500005\&lng=en

BARBEDO, C.J.; NAKAGAWA, J.; BARBEDO, A.S.C.; ZANIN, A.C.W Qualidade fisiológica de sementes de pepino cv. Pérola, em função da idade e do tempo de repouso pós-colheita dos frutos. Pesquisa Agropecuária Brasileira, v.32, p.905-913, 1997.http://www.scielo.br/scielo.php?script=sci nlinks\&ref $=000071 \& \mathrm{pid}=\mathrm{S} 14137054200800050002000004 \& \operatorname{lng}=\mathrm{en}$ 
BEWLEY, J.D.; BLACK, M. Seeds: physiology of development and germination. 2.ed, New York: Plenum Press, 1994. 445 p.

BRASIL. Ministério da Agricultura, Pecuária e Abastecimento. Regras para análise de sementes. Ministério da Agricultura, Pecuária e Abastecimento. Secretaria de Defesa Agropecuária. Brasília: MAPA/ACS, 2009. 395p. http:/ www.agricultura.gov.br/arq_editor/file/2946_regras_analise_sementes.pdf

BRASIL. Ministério da Agricultura, Pecuária e Abastecimento. Portaria no. 457 , de 18 de dezembro de 1986. Estabelece os padrões de sementes olerícolas para distribuição. Diário Oficial da União, Poder Executivo, Brasília, DF, p. 19653, 23 dez. 1986. 395 p.

CARVALHO, N.M.; NAKAGAWA, J. Sementes: ciência, tecnologia e produção. 4.ed. Jaboticabal: FUNEP, 2000. 588 p.

COSTA, C.J.; CARMONA, R.; NASCIMENTO, W.M. Idade e tempo de armazenamento de frutos e qualidade fisiológica de sementes de abóbora híbrida. Revista Brasileira de Sementes, v.28, p.127-132, 2006. http:// www.scielo.br/scielo.php?script=sci_nlinks\&ref $=000068 \&$ pid $=$ S0101 $3122201000030000200005 \& \operatorname{lng}=$ en

DUARTE, E.F.; CARNEIRO, I.F. Qualidade fisiológica de sementes de Dyckia goehringii Gross \& Rauh (Bromeliaceae) em função do estádio de maturação dos frutos. Bioscience Journal, v.25, p.161-171, 2009. http:// dx.doi.org/10.1590/S0101-31222012000300011

DUSSERT, S.; DAVEY, M.W.; LAFFARGUE, A.; DOULBEAU, S.; SWENNEN, R.; ETIENNE, H. Oxidative stress, phospholipids loss and lipid hydrolysis during drying and storage of intermediate seeds. Physiologia Plantarum, v.127, p.192-204, 2006. http://onlinelibrary.wiley.com/ doi/10.1111/j.1399-3054.2006.00666.x/full

FARIA, M.A.V.R., VON PINHO, R.G., VON PINHO, E.V.R., GUIMARÃES, R.M.; FREITAS, F.E.O. Germinabilidade e tolerância à dessecação em sementes de milho colhidas em diferentes estádios de maturação. Revista Brasileira de Milho e Sorgo, v.3, 276-289, 2004. http:// www.scielo.br/scielo.php?script $=$ sci_nlinks\&ref $=000073 \&$ pid $=$ S0 101 $3122200900040001200012 \& \operatorname{lng}=\mathrm{en}$

HAN, B.; HUGHES, W.; GALAU, G.A.; BEWLEY, J.D.; KERMODE, A.R. Changes in late-embryogenesis - abundant (LEA) messenger RNAs and dehydrins during maturation and premature drying of Ricinus communis L. seeds. Planta, v.201, p.27-35, 1997. link.springer.com/ article/10.1007\%2FBF01258677

HOEKSTRA, F.A.; GOLOVINA, E.A.; BUITINK, J. Mechanisms of plant desiccation tolerance. Trends in Plant Science, v.6. p.431-438, 2001. http://www.scielo.br/scielo.php?script=sci nlinks\&ref=000139\&pid $=$ S01039016200800060001200019\&lng $=p t$

HONG-BO, S.; ZONG-SUO, L; MING-AN, S. LEA proteins in higher plants: Structure, function, gene expression and regulation. Colloids Surf. B. Biointerfaces, v.42, p.107-113, 2005. www.ncbi.nlm.nih.gov/ pubmed/16199145
LABOURIAU, L.G. A germinação das sementes. Washington: Secretaria Geral da Organização dos Estados Americanos, 1983. 174 p.

MARCOS-FILHO, J. Fisiologia de sementes de plantas cultivadas. Piracicaba: FEALQ, 2005. 495 p

MONDO, V.H.V.; CICERO, S.M.; DOURADO-NETO, D.; PUPIM, T.L.; DIAS, M.A.N. Vigor de sementes e desempenho de plantas de milho Revista Brasileira de Sementes, v.34, n.1, p. 143 - 155, 2012. http://dx.doi. org/10.1590/S0101-31222012000100018

NAKADA, P.G.; OLIVEIRA, J.A.; MELO, L.C.; GOMES, L.A.A.; VON PINHO, E.V.R. Desempenho fisiológico e bioquímico de sementes de pepino nos diferentes estádios de maturação. Revista Brasileira de Sementes, v.33, p.113-122, 2011. http://dx.doi.org/10.1590/S0101-31222011000100013

NASCIMENTO, W.M.; PESSOA, H.B.S.V.; SILVA, P.P. Produção de sementes híbridas de abóbora do tipo tetsukabuto. Palestra XI Curso Sobre Tecnologia de Produção de Sementes de Hortaliças. 8. ed. Porto Alegre: 2011. CD-ROM.

NASCIMENTO, W.M.; FREITAS, R.A.; CRODA, M.D. Conservação de sementes de hortaliças na agricultura familiar. Brasília: Comunicado Técnico 54, 2008. p.1-5.

VIDIGAL，D.S.; DIAS， D.C.F.S.; NAVEIRA，D.S.P.; ROCHA，F.B.; BHERING, M.C. Qualidade fisiológica de sementes de tomate em função da idade e do armazenamento pós-colheita dos frutos. Revista Brasileira de Sementes, v.28, p.87-93, 2006. http://www.scielo.br/scielo.php?script=sci nlinks\&ref $=000119 \& p i d=S 0101-3122200900020001500027 \& \operatorname{lng}=p t$

VIDIGAL, D.S.; DIAS, D.C.F.S.; VON PINHO, E.V.R.; DIAS, L.A.S. Sweet pepper seed quality and Lea protein activity in relation to fruit and post-harvest storage. Revista Brasileira de Sementes, v.31, p.192-201, 2009a. http:// www.scielo.br/scielo.php?script $=$ sci nlinks\&ref $=000150 \&$ pid $=S 0100$ 204X201300120000300030\&lng=en

VIDIGAL, D.S.; DIAS, D.C.F.S.; VON PINHO, E.V.R.; DIAS, L.A.S. Alterações fisiológicas e enzimáticas durante a maturação de sementes de pimenta (Capsicum annuum L.). Revista Brasileira de Sementes, v.31, p.129136, 2009b. http://dx.doi.org/10.1590/S0101-31222009000200015

VIDIGAL, D.S.; LIMA, J.S.; BHERING, M.C; DIAS, D.C.F.S. Teste de condutividade elétrica para sementes de pimenta. Revista Brasileira de Sementes, v.30, p.168-174, 2008. http://www.scielo.br/scielo.php?script=sci nlinks\&ref=000108\&pid=S0101-3122200900030000800017\&lng=en

WELBAUM, G.E.; BRADFORD, K.J. Water relations of seed development and germination in muskmelon (Cucumis melo L.). In. Water relations of seeds and fruit development. Plant Physiology, v.86, p.406-411, 1988. http:// www.scielo.br/scielo.php?script=sci_nlinks\&ref=000104\&pid=S0101$3122200200010002200021 \& \operatorname{lng}=\mathrm{en}$ 